\title{
SINTESIS PROTEIN MIKROBA RUMEN DAN PRODUKSI GAS IN VITRO PAKAN YANG DITAMBAH UREA MOLASSES BLOCK (UMB) YANG MENGANDUNG RAGI TAPE SEBAGAI SUMBER PROBIOTIK
}

\author{
Rumen Microbial Protein Synthesis and In Vitro Gas Production of Feed \\ Supplemented with Urea Molasses Block (UMB) Containing Yeast as Probiotic \\ Zarina Cahyaningtyas ${ }^{1)}$, Kusmartono ${ }^{2)}$, dan Marjuki ${ }^{2)}$ \\ 1) Mahasiswa Bagian Nutrisi dan Makanan Ternak, Fakultas Peternakan, Universitas Brawijaya Jalan \\ Veteran, Ketawanggede, Kec. Lowokwaru, Kota Malang, Jawa Timur 65145 \\ 2) Dosen Bagian Nutrisi dan Makanan Ternak, Fakultas Peternakan, Universitas Brawijaya Jalan Veteran, \\ Ketawanggede, Kec. Lowokwaru, Kota Malang, Jawa Timur 65145 \\ Email: zarinacn@gmail.com
}

\begin{abstract}
ABSTRAK
Tujuan penelitian ini untuk mengetahui proporsi terbaik dari pengaruh penambahan ragi tape dalam UMB sebagai sumber probiotik terhadap sintesis protein mikroba rumen dan produksi gas secara in vitro. Materi pada penelitian ini adalah bahan penyusun UMB yang terdiri dari molasses, semen, pollard, urea, mineral mix, garam, ragi tape. Metode pengukuran produksi gas secara in vitro menggunakan cairan rumen yang diambil dari sapi PFH berfistula. Sampel rumput gajah diambil dari Laboratorium Lapang Fakultas Peternakan Universitas Brawijaya dan konsentrat dari KUD Pujon. Penelitian ini menggunakan Rancangan Acak Lengkap (RAL) yang terdiri dari empat perlakuan dan tiga ulangan. Data yang diperoleh dianalisis menggunakan Analysis of Variance (ANOVA), apabila hasil uji menunjukkan adanya perbedaan maka dilakukan uji lanjutan menggunakan Uji Jarak Berganda Duncan (UJBD). Hasil analisis ragam menunjukkan bahwa perlakuan penambahan ragi tape pada permbuatan $U M B$ memberikan pengaruh yang sangat nyata $(P<0,01)$ terhadap nilai produksi gas total inkubasi 48 jam dan nilai potensi produksi gas (b), serta tidak berbeda nyata $(P>0,05)$ terhadap nilai laju produksi gas $(c)$ dan sintesis protein mikroba rumen. Perlakuan terbaik ada pada P2 yaitu UMB dengan penambahan ragi tape sebesar $4 \%$. Berdasarkan hasil penelitian ini maka disarankan untuk dilakukan penelitian lebih lanjut secara in vivo untuk mengetahui respon.
\end{abstract}

Kata kunci: Sintesis protein mikroba rumen, produksi gas, ragi tape, urea molasses block, probiotik

How to Cite:

Cahyaningtyas, Z., Kusmartono., \& Marjuki. (2019). Sintesis Protein Mikroba Rumen dan Produksi Gas in Vitro Pakan yang Ditambah Urea Molasses Block (UMB) yang Mengandung Ragi Tape Sebagai Sumber Probiotik. Jurnal Nutrisi Ternak Tropis 2 (2) $38-46$
*Corresponding author:

Zarina Cahyaningtyas

Email: zarinacn@gmail.com

Fakultas Peternakan, Universitas Brawijaya Jalan

Veteran, Ketawanggede, Kec. Lowokwaru, Kota

Malang, Jawa Timur 65145 


\section{ABSTRACT}

The objectif of this research was to investigate the effect of yeast addition as probiotic source in Urea Molasses Block (UMB) as feed supplement on microbial protein synthesis and in vitro gas production. The diet consist of Elephant grass and concentrate (1:1 ratio in DM basis). The material used were molasses, cement, rice bran, urea, mineral mix, salt, and yeast as UMB's ingredients. In vitro gas production technic used ruminal fluid from fistulated cattle. Elephant grass was obtained from Field Laboratory, Animal Science Faculty, Brawijaya University and concentrate concentrate produced by Pujon dairy cooperative. This research was conducted with Completely Randomized Design (CRD) with four treatments and three replications. Data were analyzed by using Analysis of Variance (ANOVA) and Duncan's Multiple Range Test (DMRT). UMB containing different level of yeast as feed supplement gave high significant effect $(P<0.01)$ on total gas production and potential gas production value $(b$ value) but did not give significant effect $(P>0.05)$ on microbial protein synthesis and gas production rate value (c value). The best treatment was T2 UMB containing $4 \%$ yeast that produced the highest value on microbial protein synthesis, total gas production, $b$ value and $c$ value.

Keywords: Microbial protein synthesis, gas production, yeast, urea molasses block, probiotic

\section{PENDAHULUAN}

Salah satu masalah utama yang menyebabkan rendahnya produktivitas sapi perah adalah faktor pakan. Pakan hijauan yang diberikan untuk sapi perah biasanya 10 $\%$ dari bobot hidup dan pakan tambahan berupa konsentrat yang komponennya terdiri dari beberapa bahan pakan bernilai nutrisi tinggi. Akan tetapi biasanya peternak terkendala oleh pengetahuan yang kurang dan modal yang tersedia tidak terlalu banyak, sehingga peternak lebih mengandalkan hijauan dan konsentrat yang tersedia di sekitar.

Tindakan peternak mengandalkan jenis pakan yang tersedia di alam, seringkali membuat ternak tidak mendapatkan nutrisi yang cukup karena kualitas dan kuantitas hijauan akan mengalami penurunan saat musim kemarau. Selain itu, peningkatan jumlah hijauan juga dibatasi oleh semakin sempitnya lahan sebagai akibat dari meningkatnya jumlah penduduk dan pembukaan lahan baru untuk tanaman pangan maupun pembangunan gedung. Winugroho, Widiawati dan Andi (2008) menyatakan bahwa dalam rangka meningkatkan produktivitas ternak ruminansia dilakukan beberapa cara salah satunya adalah melalui pemberian pakan aditif baik berupa probiotik, vitamin, mineral maupun herbal.

Salah satu aditif pakan yang dapat digunakan adalah probiotik. Penggunaan probiotik di Indonesia dilaporkan dapat memberikan pengaruh positif terhadap ternak ruminansia. Probiotik pada ternak ruminansia dapat digunakan sebagai pemicu tingginya produksi susu sapi perah, pertambahan bobot hidup, dan efisiensi pakan pada penggemukan sapi potong (Yoon dan Stern, 1995; Winugroho et al., 1995; Haryanto et al., 1998 dalam Thalib, Haryanto, Hamid, Suherman dan Mulyani, 2001). Penggunaan probiotik pada pakan salah satunya dapat dilakukan melalui penambahan pada Urea Molasses Block (UMB) yang kemudian akan menghasilkan produk suplemen berupa Urea Molasses Probiotic Block (UMPB).

UMB adalah suplemen pakan dengan bentuk padatan/blok yang tersusun dari bahan-bahan sumber energi, protein dan mineral. Menurut Farizal (2008) sumber karbohidrat seperti onggok, molasses atau dedak yang dikombinasikan dengan bahan pakan sumber protein seperti tepung kedelai serta urea sumber NPN dapat meningkatkan pemanfaatan bahan pakan dalam sistem 
pencernaan dikarenakan mampu untuk saling melengkapi. Pertumbuhan mikroba rumen dan fermentasi dalam pakan dapat dipengaruhi oleh peningkatan bahan pakan dalam sistem pencernaan tersebut.

\section{MATERI DAN METODE}

Materi yang digunakan dalam penelitian yaitu bahan penyusun UMPB yang meliputi molasses, semen, pollard, urea, mineral mix, garam, ragi tape, cairan rumen yang diambil dari sapi $\mathrm{PFH}$ berfistula, rumput gajah yang diambil dari Laboratorium Lapang Sumbersekar dan konsentrat KUD Pujon. Bahan penelitian terdiri dari larutan supernatan, air es, aseton, larutan NDS, gas $\mathrm{CO}_{2}$, aquadest, vaselin, larutan buffer, larutan makro mineral, larutan mikro mineral, larutan resazurin, dan reduktor.
Penelitian ini menggunakan metode percobaan dengan Rancangan Acak Lengkap (RAL) yang meliputi empat perlakuan dan tiga ulangan. Berikut susunan perlakuan pada penelitian ini:

P0: $50 \%$ rumput gajah $+50 \%$ konsentrat + $10 \%$ UMB dengan ragi tape $0 \%$

P1: $50 \%$ rumput gajah $+50 \%$ konsentrat + $10 \%$ UMB dengan ragi tape $2 \%$

P2: $50 \%$ rumput gajah $+50 \%$ konsentrat + $10 \%$ UMB dengan ragi tape $4 \%$

P3: $50 \%$ rumput gajah $+50 \%$ konsentrat + $10 \%$ UMB dengan ragi tape $6 \%$

\section{VARIABEL PENGAMATAN \\ Sintesis Protein Mikroba Rumen}

Penghitingan sintesis protein mikroba rumen dapat menggunakan persamaan menurut Blummel et al. (1997), sebagai berikut:

Biomassa mikroba $(\mathrm{mg})=$ berat BK residu apparent undegradability - berat BK residu true undegradability

$\operatorname{SPM}(\mathrm{g} \mathrm{N} / \mathrm{kg}$ BOTR $)=$ biomassa mikroba (gr) x N mikroba (\%) x 1000/BOTR (kg)

\section{Pengukuran Produksi Gas secara In Vitro}

Produksi gas merupakan indikator dalam menentukan laju fermentasi dan dapat digunakan dalam penggambaran besarnya jumlah komponen zat nutrisi terutama karbohidrat tercerna dalam rumen ternak ruminansia (Suryadi dkk.,2009). Pengukuran produksi gas dilakukan pada waktu inkubasi ke 0, 2, 4, 6, 8, 12, 24 dan 48 (Makkar, 1995).

\section{Nilai Potensi Produksi Gas dan Nilai Laju Produksi Gas}

Nilai potensi produksi gas (b) dan nilai laju produksi gas (c) ditentukan dengan persamaan Makkar et al. (1995) dan dihitung menggunakan program SPSS. Persamaan yang digunakan yaitu:

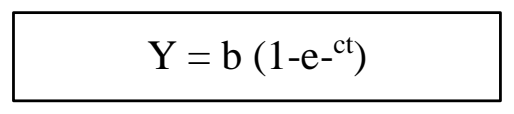

Keterangan:

$\mathrm{Y}=$ Produksi gas pada saat $\mathrm{t}(\mathrm{ml} / 500 \mathrm{mg}$

$\mathrm{BK})$;

$\mathrm{b}=$ Potensi produksi gas $(\mathrm{ml} / 500 \mathrm{mg} \mathrm{BK})$ pada " $t$ ";

$\mathrm{c}=$ Laju produksi gas ( $\mathrm{ml} / \mathrm{jam})$;

$\mathrm{t}=$ Waktu inkubasi (jam);

$\mathrm{e}=$ Eksponensia

\section{Analisis Data}

Data yang didapatkan diinput dalam program Microsoft Excel kemudian dianalisis statistik dengan menggunakan Analysis of Variance (ANOVA) dengan 
model Rancangan Acak Lengkap (RAL). Apabila terdapat perbedaan yang nyata atau sangat nyata antara tiap perlakuan maka dilanjutkan dengan Uji Jarak Berganda Duncan (UJBD)

\section{HASIL DAN PEMBAHASAN}

Hasil analisis kandungan zat nutrisi dalam bahan pakan dapat dilihat pada Tabel di bawah ini.

Tabel 1. Kandungan zat nutrisi bahan pakan

\begin{tabular}{cccccc}
\hline No & Sampel & BK $(\%)$ & BO $(\%$ BK $)$ & SK $(\%$ BK $)$ & PK $(\%$ BK $)$ \\
\hline 1 & Rumput Gajah & 15,62 & 83,50 & 30,96 & 10,42 \\
2 & Konsentrat & 90,35 & 88,17 & 16,20 & 17,08 \\
3 & Rumput Gajah + Konsentrat & 90,91 & 85,01 & 24,72 & 13,82 \\
4 & Ragi Tape & $\mathrm{ta}^{*}$ & $\mathrm{ta}^{*}$ & $\mathrm{ta}^{*}$ & 9,21 \\
5 & UMB P0 & 88,66 & 67,50 & 3,70 & 33,08 \\
6 & UMB P1 & 90,12 & 68,13 & 3,82 & 32,48 \\
7 & UMB P2 & 90,85 & 68,82 & 3,53 & 32,34 \\
8 & UMB P3 & 90,61 & 69,78 & 3,65 & 31,26 \\
\hline
\end{tabular}

Keterangan: 1. Hasil analisis Laboratorium Nutrisi dan Makanan Ternak Fakultas Peternakan Universitas Brawijaya

2. * Tidak dianalisis

Berdasarkan Tabel 1. diketahui bahwa kandungan nutrien pada UMB dengan penambahan ragi tape yaitu $\mathrm{PO}$ memiliki kandungan BK 88,66\%, BO $67,50 \%$, SK 3,70\% dan PK 33,08\%. UMB P1 mengandung BK 90,12\%, BO 68,13\%, SK $3,82 \%$ dan PK 32,48\%. UMB P2 mengandung BK 90,85\%, BO 68,82\%, SK $3,53 \%$ dan PK 32,34\%. UMB P3 mengandung BK 90,61\%, BO 69,78\%, SK $3,65 \%$ dan PK $31,26 \%$. Formula bahan penyusun UMB mengacu pada penelitian yang dilakukan oleh Ghebrehiwet, Wangdi dan Ibarhim (1994) yang menghasilkan UMB dengan kandungan BK 87,3\%, PK $43,1 \%$ dan abu 23,8\%. Perbedaan kandungan nutrien pada UMB diduga terjadi karena adanya perbedaan kualitas bahan pakan yang digunakan. Semakin rendah kualitas bahan yang digunakan, semakin rendah kandungan nutrisi UMB yang dihasilkan.
Hasil penelitian menunjukkan bahwa semakin tinggi jumlah penambahan ragi tape pada UMB semakin rendah kandungan protein kasarnya. Hal tersebut kemungkinan terjadi karena ragi tape yang ditambahkan pada UMB memiliki kandungan protein kasar yang rendah yaitu sebesar 9,21\%. Rendahnya kandungan protein kasar pada ragi diduga disebabkan oleh lebih banyaknya media kultur yang digunakan sebagai penyusun ragi daripada starter mikroba yang terkandung di dalamnya. Penambahan ragi tape yang memiliki protein kasar rendah, akan menurunkan kandungan protein kasar pada UMB.

\section{Sintesis Protein Mikroba Rumen}

Hasil analisis sintesis protein mikroba rumen pakan dengan penambahan UMB yang mengandung ragi tape sebagai sumber probiotik pada setiap perlakuan dapat dilihat pada Tabel di bawah ini. 
Tabel 2. Rata-rata nilai sintesis protein mikroba rumen dari pakan yang disuplementasi UMB yang mengandung jumlah ragi tape yang berbeda.

Perlakuan Sintesis Protein Mikroba Rumen (g N/kg BOTR)

\begin{tabular}{ll}
\hline P0 & $45,49 \pm 1,768^{\mathrm{a}}$ \\
P1 & $46,68 \pm 0,723^{\mathrm{a}}$ \\
P2 & $47,16 \pm 0,809^{\mathrm{a}}$ \\
P3 & $46,74 \pm 2,205^{\mathrm{a}}$ \\
\hline
\end{tabular}

Keterangan: Superskrip yang sama menunjukkan tidak adanya perbedaan yang nyata $(\mathrm{P}>0,05)$

Berdasarkan hasil penelitian menunjukkan penambahan ragi tape dalam pembuatan UMB tidak memberikan pengaruh nyata terhadap sintesis protein mikroba rumen $(\mathrm{P}>0,05)$. Sintesis protein mikroba pada penelitian ini berkisar antara 45,49-47,16 g N/kg BOTR. ARC (1984) dalam Sairullah, Chuzaemi dan Sudarwati (2016) menjelaskan bahwa rataan protein mikroba untuk semua bahan pakan pada ternak ruminansia yang terfermentasikan di dalam rumen, berkisar antara 15-45 g N/kg BOTR atau rata-rata $30 \mathrm{~g} \mathrm{~N} / \mathrm{kg}$ BOTR. Pakan yang digunakan pada penelitian yaitu rumput gajah dan konsentrat yang ditambah dengan pakan suplemen susmber protein sehingga nilai sintesis protein mikroba rumen yang dihasilkan lebih tinggi daripada rata-rata.

Berdasarkan Tabel 2, diketahui bahwa P1, P2 dan P3 yaitu UMB yang mengandung ragi tape memberikan nilai sintesis protein mikroba rumen yang lebih tinggi daripada P0 tanpa penambahan ragi tape. Penambahan ragi tape sebanyak $4 \%$ dalam pembuatan UMB merupakan jumlah pemberian optimal karena menghasilkan nilai sintesis protein mikroba rumen tertinggi yaitu pada perlakuan P2 sebesar 47,16 g N/kg BOTR, sedangkan hasil terendah terdapat pada perlakuan $\mathrm{P} 0$ yaitu sebesar 45,49\%. Menurut pendapat Wina (1999), kultur ragi yang ditambahkan dalam pakan mampu mempercepat pertumbuhan bakteri anaerob rumen. Sehingga populasi bakteri rumen meningkat terutama bakteri asam laktat dan bakteri selulolitik. Sapi yang diberikan bakteri ragi sampai 10 kali lipat meningkat dibandingkan dengan yang tanpa diberi perlakuan (kontrol) Dawson, Newman, dan Boling (1990). Total bakteri selulolitik lebih besar dari total populasi pada fermentasi secara in vitro. Komposisi bakteri dan kondisi fermentasi rumen dapat dipengaruhi oleh populasi bakteri tertentu. Peningkatan populasi bakteri selulolitik mempengaruhi peningkatan aktivitas selulolitik dan mampu mengurangi waktu yang dibutuhkan untuk mencerna serat sekitar 30\% dengan adanya penambahan ragi. Peningkatan populasi bakteri asam laktat dapat meningkatkan metabolisme asam laktat menjadi asam propionat. Penurunan asam laktat akan mengakibatkan $\mathrm{pH}$ rumen menjadi lebih stabil.

Konsumsi bahan kering, suplai senyawa nitrogen, suplai energi terfermentasi, rasio hijauan dengan konsentrat pada ransum, sinkronisasi nitrogen dan energi, lingkungan rumen, laju makanan, vitamin dan mineral merupakan faktor yang mempengaruhi sintesis protein mikroba adalah (Pathak, 2008). Adanya kandungan molases dan urea dalam UMB merupakan salah satu faktor yang mengakibatkan meningkatnya sintesis protein mikroba rumen dalam penelitian yang dilakukan.

Murtidjo (1990) menjelaskan bahwa sumber energi utama bagi mikroba rumen adalah karbohidrat sederhana berupa glukosa. Selain itu, glukosa juga digunakan 
oleh mikroba sebagai rantai karbon pada proses sintesis protein pada tubuhnya. Populasi mikroba rumen akan meningkat ketika ketersediaan nutrien memenuhi kebutuhan mikroba. Hal ini mampu meningkatkan sintesis protein. Sintesis protein membutuhkan non protein nitrogen dan sumber karbohidrat dari pakan.

\section{Produksi Gas In Vitro serta Parameternya}

Pola kenaikan produksi gas pakan dengan penambahan UMB yang mengandung ragi tape sebagai sumber probiotik dengan proporsi yang berbeda pada setiap perlakuan dapat dilihat pada Gambar 1.

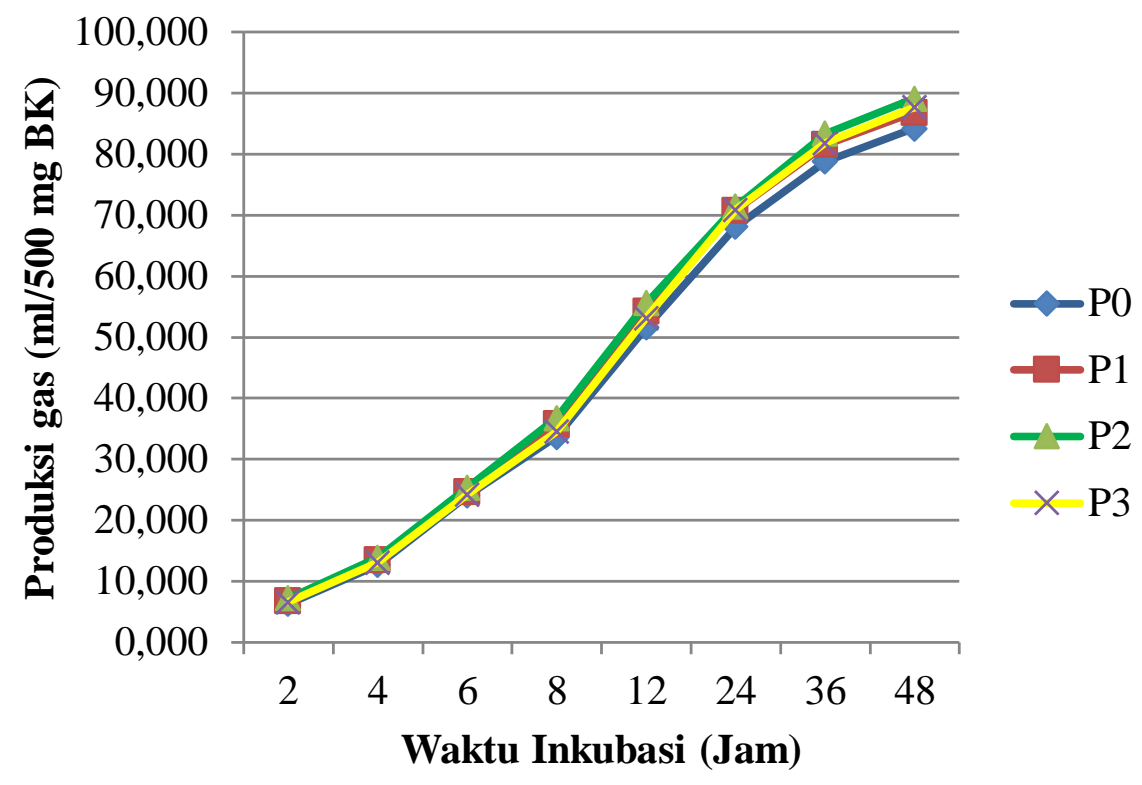

Gambar 1. Produksi gas pakan dengan penambahan UMB yang mengandung ragi tape masing-masing perlakuan

Kurva peningkatan produksi gas seperti yang dapat dilihat pada Gambar 1, terjadi sesuai dengan aktivitas dan perkembangan mikroba dalam rumen. Pada umumnya, terdapat 4 fase perkembangan mikroba yaitu lag, log, stationary dan death phase yang membentuk kurva sigmoid (berbentuk S) sehingga produk fermentasi yang dihasilkan berbanding lurus dengan perkembangan mikroba. Peningkatan produksi gas terjadi secara lambat dari jam ke 0 hingga jam ke 6 inkubasi karena pertumbuhan mikroba berada pada fase lag atau adaptasi dimana mikroba mulai beradaptasi dengan lingkungan barunya.

Tahapan sintesis protein mikroba terhadap zat nutrisi diawali dengan fermentasi mikroba rumen Firsoni dan Ansori (2015). Kemudian adanya urea mampu dimanfaatkan untuk fermentasi dan sintesis protein mikroba rumen berdasarkan ketersediaan karbohidrat. Mikroba rumen dipengaruhi oleh ketersediaan amonia, asam amino dan sumber energi hasil degradasi pakan setelah terjadi metabolisme di dalam rumen untuk penyediaan biomassa. Karbohidrat dan protein yang terdegradasi secara langsung akan dimanfaatkan untuk sintesis protein mikroba yang dibuktikan dengan terjadinya peningkatan produksi gas yang tinggi pada jam ke 6 hingga 24 inkubasi. Produksi gas pada 24 jam terakhir inkubasi tetap mengalami peningkatan namun jumlahnya sangat sedikit jika dibandingkan dengan kenaikan produksi gas pada 24 jam pertama. Hal tersebut terjadi karena mikroba berada pada fase stationary dan berlanjut pada fase kematian dimana ketersediaan substrat sebagai sumber makanan untuk pertumbuhan mikroba 
semakin menurun seiring dengan difermentasi akan berakibat pada penurunan meningkatnya waktu inkubasi. produksi gas yang merupakan hasil Berkurangnya jumlah substrat yang dapat fermentasi (Jayanegara dan Sofyan, 2008).

Tabel 3. Rata-rata produksi gas total inkubasi 48 jam, nilai potensi produksi gas (b) dan laju produksi gas (c) pakan dengan UMB yang mengandung ragi tape

\begin{tabular}{cccc}
\hline Perlakuan & $\begin{array}{c}\text { Produksi gas total inkubasi } \\
48 \text { jam }(\mathrm{ml} / 500 \mathrm{mg} \mathrm{BK})\end{array}$ & $\begin{array}{c}\mathrm{b} \\
(\mathrm{ml} / 500 \mathrm{mg} \mathrm{BK})\end{array}$ & $\begin{array}{c}\mathrm{c} \\
(\mathrm{ml} / \mathrm{jam})\end{array}$ \\
\hline P0 & $84,28 \pm 1,169^{\mathrm{a}}$ & $90,95 \pm 1,949^{\mathrm{a}}$ & $0,0573 \pm 0,00289^{\mathrm{a}}$ \\
P1 & $86,87 \pm 1,085^{\mathrm{ab}}$ & $93,68 \pm 0,290^{\mathrm{ab}}$ & $0,0590 \pm 0,00500^{\mathrm{a}}$ \\
P2 & $89,17 \pm 1,312^{\mathrm{b}}$ & $95,15 \pm 0,902^{\mathrm{b}}$ & $0,0597 \pm 0,00513^{\mathrm{a}}$ \\
P3 & $87,72 \pm 1,378^{\mathrm{b}}$ & $94,85 \pm 0,292^{\mathrm{b}}$ & $0,0567 \pm 0,00404^{\mathrm{a}}$ \\
\hline
\end{tabular}

Keterangan: - Superskrip yang berbeda pada kolom produksi gas total inkubasi 48 jam dan nilai $\mathrm{b}$ menunjukkan perbedaan yang sangat nyata $(\mathrm{P}<0,01)$

- Superskrip yang sama pada kolom nilai c menunjukkan tidak adanya perbedaan yang nyata $(\mathrm{P}>0,05)$

Tabel 3 menunjukkan hasil analisis produksi gas, nilai potensi produksi gas (b) dan nilai laju produksi gas (c) UMB dengan penambahan ragi tape sebagai sumber probiotik. Berdasarkan hasil penelitian menunjukkan bahwa pembuatan UMB dengan level penambahan ragi tape dengan perbedaan proporsi memberikan pengaruh yang sangat nyata $(\mathrm{P}<0,01)$ terhadap produksi gas total inkubasi 48 jam dan nilai b namun tidak memberikan pengaruh yang nyata $(\mathrm{P}>0,05)$ terhadap nilai $\mathrm{c}$.

Pada Tabel 3 menunjukkan bahwa UMB yang mengandung ragi tape $(\mathrm{P} 1, \mathrm{P} 2$, dan P3) menghasilkan nilai produksi gas dan potensi produksi gas yang lebih tinggi dari pada UMB tanpa penambahan ragi tape (P0). Hal tersebut terjadi karena dalam ragi tape terdapat beberapa jenis mikroorganisme yang berperan sebagai probiotik sehingga dapat meningkatkan jenis dan jumlah mikroba yang akhirnya dapat meningkatkan kecernaan melalui perbaikan proses fermentasi yang terjadi dalam rumen. Menurut pendapat Sugoro, Gobel dan Lelananingtyas (2005) menyatakan bahwa probiotik jenis khamir pada rumen mampu meningkatkan produksi gas, biomassa bakteri, konsentrasi asam lemak terbang (ALT), $\mathrm{pH}$ dan kecernaan bahan kering, bahan organik dan komponen serat neutral ditergent fiber (NDF).

Perlakuan P2 dengan penambahan ragi tape sebesar $4 \%$ menunjukkan hasil tertinggi pada produksi gas total inkubasi 48 jam daripada perlakuan P0, P1 dan P3 yaitu $89,1670 \mathrm{ml} / 500 \mathrm{mg}$ BK. Hal ini diduga disebabkan karena penambahan $4 \%$ ragi tape pada pembuatan UMB merupakan imbangan yang sesuai untuk pemberian probiotik pada ruminansia. Wina (1999) menyatakan bahwa penambahan kultur ragi dalam jumlah sedikit terhadap pakan ruminansia mampu meningkatkan bobot badan dan menurunkan konversi pakan.

Nilai rata-rata produksi gas merupakan parameter bahan organik (BO) yang potensial terfermentasi di dalam rumen (b) dan laju produksi gas merupakan laju fermentasi per jam (c) dari pakan. Nilai b yang ditunjukkan pada Tabel 3 yaitu berkisar antara 90,95-95,15 ml/500 mg BK. Nilai b tertinggi terdapat pada P2 (penambahan ragi tape sebanyak $4 \%$ ) sebesar 95,15 ml/500 mg BK. Hal tersebut diduga karena pengaruh hubungannya dengan tingkat kecernaan. Berdasarkan penelitian yang dilakukan oleh Anggoro (2018), penambahan ragi tape sebesar $4 \%$ dalam pembuatan UMB memberikan nilai 
KcBO tertinggi dibandingkan dengan perlakuan yang lainnya yaitu sebesar $65,61 \%$. Menurut Khoiriyah, Chuzaemi dan Sudarwati (2016), terdapat korelasi antara nilai potensi produksi gas dengan $\mathrm{KcBO}$ sehingga semakin tinggi nilai potensi produksi gas adalah ekspresi dari meningkatnya $\mathrm{KcBO}$.

Penambahan ragi tape pada pembuatan UMB tidak memberikan pengaruh nyata terhadap laju produksi gas (c) $(\mathrm{P}>0,05)$. Pada Tabel 3, dapat diketahui bahwa laju produksi gas pada perlakuan $\mathrm{P} 0$, P1, P2 dan P3 berkisar antara 0,0573-0,0597 $\mathrm{ml} / \mathrm{jam}$. Nilai c berbanding lurus dengan kecernaan bahan organik dalam rumen. Seperti penjelasan Mukmin, Soetanto, Kusmartono dan Mashudi (2014) bahwa produksi gas yang rendah menunjukkan bahwa BO yang didegradasi oleh mikroba juga sedikit. Laju produksi gas berkorelasi positif dengan kecernaan BO dan konsumsi BO tercerna. Berdasarkan data pada Tabel 3, diketahui bahwa laju produksi gas pada semua perlakuan semakin meningkat antar titik pengukuran atau waktu inkubasi. Peningkatan tersebut diduga karena adanya penambahan ragi tape dalam UMB. Ragi tape merupakan sumber probiotik dalam pakan. Ragi tape mengandung Saccharomyces sp yang berperan sebagai probiotik dan meningkatkan kecernaan pakan berserat tinggi (Bidura et al., 2012 dalam Wibawa dkk. (2014).

\section{KESIMPULAN DAN SARAN}

Berdasarkan hasil penelitian dapat disimpulkan bahwa penambahan ragi tape pada pembuatan Urea Molasses Block (UMB) sebagai pakan suplemen dapat meningkatkan sintesis protein mikroba rumen dan produksi gas in vitro. Perlakuan terbaik terdapat pada $\mathrm{P} 2$ yaitu UMB dengan penambahan ragi tape sebesar $4 \%$ yang memberikan nilai tertinggi pada nilai sintesis protein mikroba rumen, produksi gas total, nilai potensi produksi gas, dan nilai laju produksi gas yaitu yaitu 47,16 $\mathrm{g} \mathrm{N} /$ kg BOTR, 89,17 ml/500 mg BK, 95,15 ml/
$500 \mathrm{mg} \mathrm{BK}$ and $0,0597 \mathrm{ml} / \mathrm{jam}$. Saran pada penelitian ini adalah penelitian lebih lanjut secara in vivo untuk mengetahui respon ternak secara langsung.

\section{DAFTAR PUSTAKA}

Anggoro, M. R. (2018). Pengaruh Urea Molasses Block (UMB) yang Mengandung Ragi Tape sebagai Sumber Probiotik terhadap Degradabilitas dan Produksi Gas Pakan Lengkap secara In Vitro. Universitas Brawijaya Malang.

ARC. (1984). The Nutrient Requirement of Ruminant Livestock. In Commonwealth Agricultural Bureaux. England: Sloug.

Blummel, M., Steingas, H., \& Becker, K. (n.d.). The relationship between in vitro gas production, in vitro biomass yield and incorporation and it is implication for the prediction of voluntri feed intake of roughages. Journal Nutrition, 77, 911-921.

Dawson, K. A., Newman, K., \& Boling, J. (1990). Effects of microbial supplements containing yeast and lactobacilli on roughage-fed ruminal microbial activities. Journal Animal Science, 68, 3392-3398.

Farizal. (2008). Respon pemberian Urea Molases Blok (UMB) dan hay rumput kumpai (Hymenaehne amplexicaulis) terhadap pertambahan bobot badan domba lokal jantan. Jurnal Ilmiah Ilmu-Ilmu Peternakan, 11(1), 24-27.

Firsoni, F., \& Ansori, D. (2016). Manfaat urea molasses multinutrien blok (UMMB) yang mengandung tepung daun glirisidia (gliricidia sepium) secara in-vitro. Jurnal Ilmiah Aplikasi Isotop Dan Radiasi, 11(2), 161-170. https://doi.org/10.17146/jair.2015.11.2.2793 
Ghebrehiwet, T., Wangdi, P., \& Ibrahim, M. N. M. (1994). Feeding rice straw supplemented with urea-molasses lick block to lactating cows in Bhutan. Asian-Australasian Journal of Animal Sciences, 7(3), 421-426. https://doi.org/10.5713/ajas.1994.421

Jayanegara, A., \& Sofyan, A. (2008). Penentuan aktivitas biologis tanin beberapa hijauan secara in vitro menggunakan "Hohenheim gas test" dengan polietilen glikol sebagai determinan. Media Peternakan, 31(1), 44-52.

Makkar, H. P. S., Blummel, M., \& Becker, K. (1995). Application of An In Vitro Gas Method to Understand The Effect of Natural Plant Product on Availability and Portitioning of Nutrients. Germany: Institute for Animal Production in The Tropic and Subtropic University of Stuttgart.

Mukmin, A., Soetanto, H., Kusmartono, \& Mashudi. (2014). Produksi gas in vitro asam amino metionin terproteksi dengan serbuk mimosa sebagai sumber condensed tannin (CT). TERNAK TROPIKA Journal of Tropical Animal Production, 15(2), 36-43.

Murtidjo, B. A. (1990). Sapi Potong. Yogyakarta: Kanisius.

Pathak, A. K. (2008). Various factors affecting microbial protein synthesis in the rumen. Vet. World, 1(6), 186-189.
Sugoro, I., Gobel, I., \& Lelananingtyas, N. (2005). Pengaruh probiotik khamir terhadap fermentasi dalam cairan rumen secara in vitro. In Seminar Nasional Teknologi Peternakan dan Veteriner.

Suryadi, S., Afdal, M., \& Latief, A. (2009). Pengaruh penggantian rumput dengan pelepah sawit ditinjau dari segi kecernaan dan fermentabilitas secara in vitro gas. Jurnal Ilmiah Ilmu-Ilmu Peternakan, 12(1), 29-34. https://doi.org/10.22437/JIIIP.V0I0.489

Thalib, A., Haryanto, B., Hamid, H., Suherman, D., \& Mulyani. (2001). Pengaruh kombinasi defaunator dan probiotik terhadap ekosistem rumen dan performan ternak domba. Jurnal Ilmu Ternak Dan Veteriner, 6(2), 83-89.

Wibawa, A. A. P. P., Trisnadewi, A. A. A. S., \& Partama, I. B. G. (1970). Suplementasi ragi dalam ransum yang mengandung ampas tahu terhadap produksi telur ayam lohmann brown. Majalah Ilmiah Peternakan, 17(3), 85-90.

https://doi.org/10.24843/MIP.2014.v17.i03.p02

Wina, E. (1999). Pemanfaatan ragi (yeast) sebagai pakan imbuhan untuk meningkatkan produktivitas ternak ruminansia. Wartazoa, 9(2), 1-8.

Winugroho, M., Widiawati, Y., \& Andi, D. (2008). Pengaruh Pemberian Feed Aditif Sozo-4 terhadap Pertambahan Bobot Hidup Sapi Brahman Cross. In Seminar Nasional Teknologi Peternakan dan Veteriner. 